\title{
Screening for minor changes in the distal part of the human dystrophin gene in Greek DMD/BMD patients
}

\author{
K iriaki Kekou, A riadni M avrou, Lina Florentin, Sotiris Youroukos, Dimitrios I Zafiriou, \\ $\mathrm{H}$ elen N Skouteli and Catherine M etaxotou
}

G enetic U nit, First D epartment of Pediatrics, A thens U niversity, 'A ghia Sophia' Children's H ospital, A thens, G reece

\begin{abstract}
The distal part of the human dystrophin gene is characterised by particular features and seems to play an important functional role. A dditionally in recent years several data have implicated minor mutations in this gene region in some patients with mental retardation (M R ). In order to screen for pathogenic mutations at the distal part of the human dystrophin gene we have used single-strand conformation analysis of products amplified by polymerase chain reaction (PCR -SSCA) in 35 unrelated male G reek D MD/BM D patients with no detectable deletions. Seven patients also had severe mental retardation. $D$ irect sequencing of samples demonstrating a shift of SSCA mobility revealed six different and pathogenic minor changes, five in D MD and one in a BMD patient. Four of the mutations were found in DMD patients with severe $M R$. Three of these mutations were localised in exon 66, which presents an interesting similarity with part of the 3 ' end of the genome of eastern equine encephalomyelitis virus (EEEV). The present data from G reek DMD/BMD patients give further information about the phenotypic effects consequent on mutations in exons at the distal part of the human dystrophin gene.
\end{abstract}

Keywords: dystrophin gene; distal part; point mutations; mental retardation

\section{Introduction}

The dystrophin gene is an enormous gene which spreads over more than $2300 \mathrm{~Kb}$, consisting of 79 exons $^{1,2}$ and encodes the protein dystrophin $(427 \mathrm{kDa})$ localised in the inner surface of the sarcolemma of muscle fibres. ${ }^{3,4}$ D efects of the gene cause the allelic neuromuscular disorders D uchenne and Becker muscular dystrophies. Two-thirds of gene mutations responsible for the disease are the result of large

Correspondence: K iriaki K ekou, G enetic U nit, 1st D epartment of Pediatrics, A thens U niversity, 'A ghia Sophia' Children's H ospital, 11527 A thens, G reece. Tel: +30 1 7467462; Fax: +30 1 7795762; E-mail: ckatamis@atlas.uoa.gr

R eceived 20 January 1998; revised 16 A pril 1998; accepted 21 July 1998 deletions which are clustered in two hot spot regions of the gene and are easily detected by a multiplex polymerase chain reaction system (multiplex PCR). ${ }^{5,6}$ The remaining third of the mutations is thought to be caused mainly by minor changes that are difficult to detect by routine analysis, due to the enormous gene size. $^{7}$

The dystrophin gene is subject to complex transcriptional and m-RNA processing control. ${ }^{8}$ In particular the $3^{\prime}$ end of the gene, which has a remarkable similarity to the corresponding region of the autosomal encoded dystrophin-related protein (DRP), ${ }^{9}$ reveals a pattern of alternative transcripts, both in normal individuals and in patients with deleterious mutations at the region. ${ }^{10,11}$ Additionally, Dp71 (coded by 
exons63-79), Dp116 (exons56-79) and Dp140 (exons 51-79) are dystrophin isoforms transcribed from alternative promoters in or near the $3^{\prime}$ end of the dystrophin gene and are localised mainly in the nervous system. ${ }^{12-14}$ R ecent data have shown that some $D M D$ cases with M R (observed in $30 \%$ of D M D patients), are associated with point mutations that disrupt the translational reading frame in the $\mathrm{C}$-terminal region and lead to loss of function concerning the expression of D p116 and/or D p71 proteins. ${ }^{15,11}$

The significant functional role of the carboxy terminus domain is evident from biochemical studies which have demonstrated that dystrophin is closely associated, through its cysteine-rich and $\mathrm{C}$-terminal domains, with the sarcolemmal membrane in a large glycoprotein complex. ${ }^{16}$ This is thought to offer linkage between the extracellular matrix and the cytoskeleton and/or stability of the plasma membrane during muscle contraction and relaxation. ${ }^{17}$

In order to study the complex role of the $3^{\prime}$ end coding region of the dystrophin gene in $35 \mathrm{Greek}$ DMD/BMD patients with no detectable deletions, we screened for pathogenic mutations at this region. Six different minor changes were revealed, consisting of three microdeletions, two nonsense mutations and one donor splice site mutation. In two cases RT-PCR analysis demonstrated exon skipping, thus confirming the pathological effect of the respective mutations. Four of the mutations were found in DMD patients with $M R$; furthermore, three of them were found in exon 66.

\section{Materials and Methods}

\section{Patients}

Thirty-five unrelated G reek patients were selected (31D M D and four BM D) for point mutation screening, in whom D M D deletions had been previously excluded using multiplex PCR. ${ }^{6}$ Seven of the DMD patients had mental and/or language impairment. Diagnosis was based on clinical examination, family history, elevated serum creatine kinase activity and progression of the disease. In 15 cases the diagnosis was confirmed by dystrophin examination of muscle biopsy with immunofluorescence analysis. In the remaining 20 cases (8familial and 12 sporadic) dystrophin analysis of muscle biopsy was not performed, either because the test was not available in Greece at the time of diagnosis, or because of family refusal.

\section{PCR-SSCA}

Exons 60-79, including intron boundaries, were amplified from genomic DNA using primers designed from sequence data in the $E M B L / G$ enBank databases (primer sequence available on request). A ll amplifications were carried out using $100 \mathrm{ng}$ of genomic D NA, $10 \mathrm{pmol}$ of each primer, $0.5 \mathrm{U}$ Taq polymerase (Promega Corporation, M adison WI, U SA), $4.5 \mathrm{~mm} \mathrm{M} \mathrm{gCl}$ and $0.2 \mathrm{~mm}$ each of dNTP. When a radioactive reaction was prepared instead of $0.2 \mathrm{~mm}$ of $\mathrm{dCTP}, 0.1 \mu \mathrm{l}$ radioactive $\left(a^{32} \mathrm{P}\right)$ was used. The cycling conditions included an initial step of $96^{\circ} \mathrm{C}$ for $4 \mathrm{~min}$, followed by 30 cycles of $93^{\circ} \mathrm{C}$ for $1 \mathrm{~min}, 58^{\circ} \mathrm{C}$ for $1 \mathrm{~min}$, and $72^{\circ} \mathrm{C}$ for $3 \mathrm{~min}$, with a final extension of $72^{\circ} \mathrm{C}$ for $5 \mathrm{~min}$.

Following amplification, $5 \mu$ l of PCR reaction were diluted with $5 \mu \mathrm{l}$ of $0.1 \% \quad \mathrm{SDS} / 1 \mathrm{~mm} \quad$ EDTA and $5 \mu \mathrm{l}$ of $98 \%$ formamide dye. $D$ iluted products were denatured by heating at $100^{\circ} \mathrm{C}$ for $5 \mathrm{~min}$ and immediately transferred to ice. Subsequently $5-10 \mu \mathrm{l}$ of each PCR mixture were electrophorised through $0.5 \mathrm{X}$ nondenaturing vertical HydrolinkMDE (FMC B ioproducts, Rockland, ME, USA) gel in TBE $0.6 \mathrm{X}$. Electrophoresis was carried out at $4 \mathrm{~W}$ for $18-23 \mathrm{~h}$ at $-4^{\circ} \mathrm{C}$. For band visualisation, alternatively with silver staining, ${ }^{18}$ autoradiography was used.

\section{$R T-P C R$}

It has been demonstrated that certain genes, including the dystrophin gene, produce ectopic transcripts (also called illegitimate), in non-specific tissues such as Iymphocytes. ${ }^{19}$ From two patients (probands D 286 and D 320) total R NA was extracted from peripheral blood lymphocytes (PBL) and reverse-transcribed using the method described by R oberts et al. ${ }^{20}$ A ccording to this protocol for the first round of PCR, primers 10a and 10b were used in both cases to amplify exons67-77 (Reaction 10). The primer pairs used in the nested PCR were selected to cover the appropriate exons indicated by the PCR -SSCA : patient D 286 who showed by PCR-SSCA a band shift in exon 70, was analysed by amplification of the region between exons 67 and 71 (primers $10 \mathrm{c}$ and 10f), and patient D 320 with a band shift in exon 74 was analysed by amplification of the region between exons 67 and 77 (primers 10c and 10d).

\section{Direct Sequencing}

PCR products were purified using the $\mathrm{Q}$ iagen purification kit (Cat. No 28104, Qiagen G mbH, Hilden, Germany). In samples with multiple PCR bands the appropriate band was eluted from $1.6 \%$ agarose gel according to the $\mathrm{Q}$ iagen gel extraction kit (Cat. No 28704, Qiagen G mbH, Hilden, Germany). Purified templates were directly sequenced with the dideoxy chain termination cycle sequencing kit (RPN 2440, A mersham, U K ), using the primers as for PCR -SSCA and RT-PCR, except for the CDNA of patient D 320 in which an inner primer (N 1 primer nucleotides 10263-81) was used. Primers were labelled with Texas R ed Labelling kit (RPN 2441, A mersham). Sequencing reactions were analysed on a Vistra automated DNA Sequencer (Vistra 725, Molecular D ynamics/A mersham L ife Science, UK ).

\section{Haplotype Analysis}

In cases where DNA from other family members was available, haplotype analysis was performed to confirm segregation of mutations in the family. The mutations were traced by SSCA in other family individuals and the results were confirmed by linkage analysis data using previously described polymorphic markers along the dystrophin gene. ${ }^{18}$ 


\section{Results}

PCR -SSCA of 35 G reek D M D /BM D patients displayed six band shifts. Direct sequencing revealed five different minor changes in the coding region and one splice site mutation (Figure 1). The clinical data of the patients with pathogenic mutations are shown in Table 1 and a summary of the molecular findings is presented in Table 2.

\section{Minor Changes and One Polymorphism in Exon 66}

Three pathogenic mutations were found in exon 66 in three unrelated DMD patients with severe mental retardation (Figure $1 \mathrm{~A}$ ). A II were familial cases with two or more affected individuals.

The mutation in patient $D 363$ is a $C$ to $T$ substitution at nucleotide 9776 which creates a nonsense mutation predicting a premature termination of translation, resulting in truncated dystrophin. M utation analysis of the family by SSCA showed that the mutation was present not only in the patient but also in his two younger brothers, aged 3 and 2 respectively, who had elevated serum kinase activity. Two second-degree relatives with DMD phenotype and cognitive impairment died at ages 15 and 16 respectively from severe cardiac failure. DNA analysis from these patients was not available. $\mathrm{H}$ aplotype analysis in the family using polymorphic markers revealed a recombinant event in the patient between intron 39 and 44 . This analysis showed that the patient and his two brothers with elevated kinase activity, share the same dystrophin haplotype only after intron 44, where the point mutation was also detected.

The mutation of patient $D 165$ is a microdeletion of $2 \mathrm{~A}$ in position 9806-9 from a 4A run which generates a stop codon (TAA), eight codons downstream. The patient (Table 1 ) is 4 years old and does not yet speak. I maging of his brain with magnetic resonance imaging (MRI) demonstrated a mild asymmetry of the lateral ventricles and areas of increased signal were seen in the periventricular white matter frontally and occipitally. From family history it is known that two maternal aunts gave birth to affected boys both of whom were wheelchair bound at the age of 8 . One of the cousins died at age 15 and the others is now 11 years old. Segregation of the SSCA band pattern in the family (the three affected boys, their mothers and their grandmother) is consistent with haplotype analysis using polymorphic markers.
The mutation in patient D 171 is a microdeletion of $8 \mathrm{bp}$ in position 9827 which generates a stop codon (TGA) 21 codons downstream. The patient is 5 years old and his family history showed that two of his maternal uncles became wheelchair bound at the age of 9 and died at the age of 15 . Genetic analysis of the family was not available.

Beside the three mutations identified in exon 66, a polymorphism was also detected in six of the 35 patients (Figure $1 \mathrm{~A}$ ). This polymorphism is a $\mathrm{C}$ to $\mathrm{T}$ transition at position +15 , in intron 66 and was also observed in 15 out of $100 \mathrm{Greek}$ unrelated normal males $(15 \%)$.

\section{Identification of a Nonsense Mutation in Exon 62}

The shift mobility which was revealed by SSCA in patient D 074 at exon 62 (Figure 1A ) showed after direct sequencing of PCR amplified products, a substitution at nucleotide 9391 ( $G$ to $A$ ) generating a stop codon (TGA). This stop codon is predicted to cause premature termination of the translation reading frame (Figure 1B ). M utation detection by SSCA on the family, showed that the mutation is also carried by the patient's mother. Furthermore, haplotype analysis with polymorphic markers showed that the proband's $X$ chromosome was of grandpaternal origin.

\section{Characterisation of a Splice Site Mutation in Intron 70}

$D$ irect sequencing of the band shift from SSCA in patient D 286 (Figure $1 A$ ) revealed a donor splice site mutation ( $G$ to $C$ ) at position +1 , intron 70 (Figure 1B). This mutation has previously been described at DNA level, in a sporadic DMD patient with some degree of mental handicap. ${ }^{21} \mathrm{O}$ ur patient is a familial case and has severe psychomotor delay and language impairment. From family history it is known that a maternal uncle was wheelchair bound at the age of 12 and died at the age of 19. The mutation in our case was also confirmed by RT-PCR analysis that revealed three frameshift products in the region of exons67-71, demonstrating activation of alternative splicing. In order to find the transcriptional effect of this donor splice site mutation, dystrophin mRNA was obtained from peripheral blood lymphocytes. RT-PCR analysis was performed between nucleotides 9974-10483 (approximately 67-71exons) and the amplification showed three different and shorter fragments (about $250 \mathrm{bp}, 370 \mathrm{bp}$ and $410 \mathrm{bp}$ respectively), instead of the one product (507 bp) expected (Figure 2$)$. Sequencing 
A

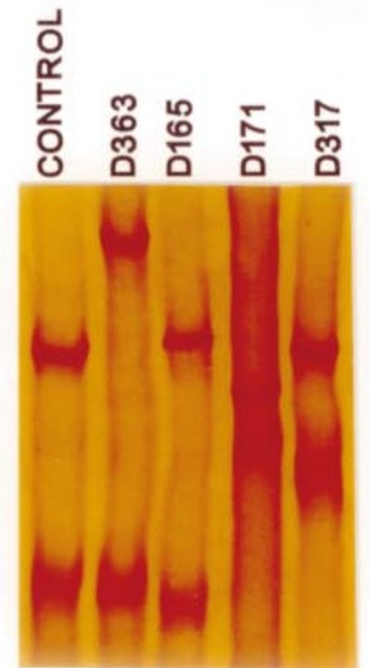

EXON 66

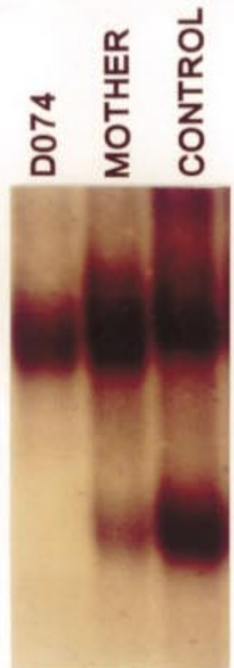

EXON 62

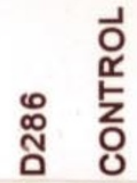

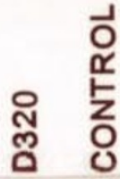

EXON 74

EXON 70

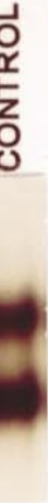

B

$5^{\prime}$

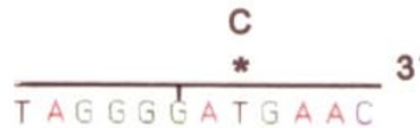

E66

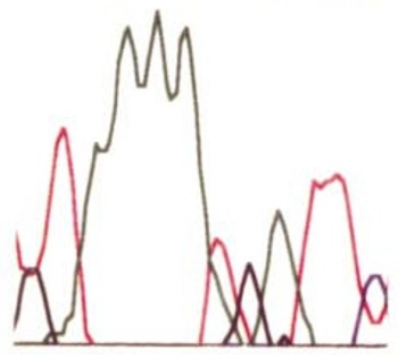

D363
E66

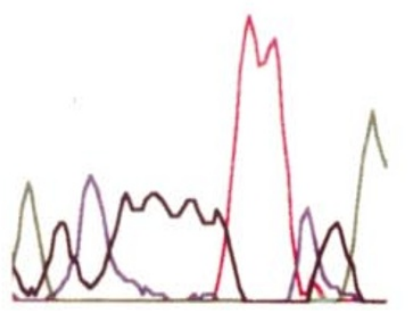

D165
-TGTAAAGC $5^{\prime}$

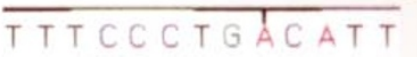

E66

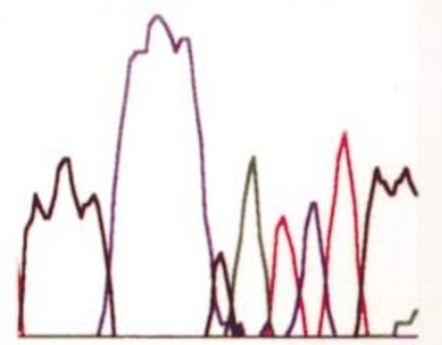

D171 $5^{\prime}$

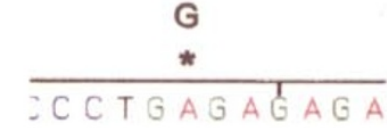

$3^{\prime}$$$
\mathbf{5}^{\prime}
$$

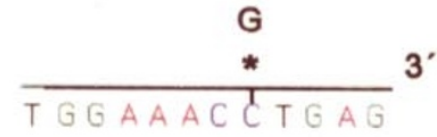

E62

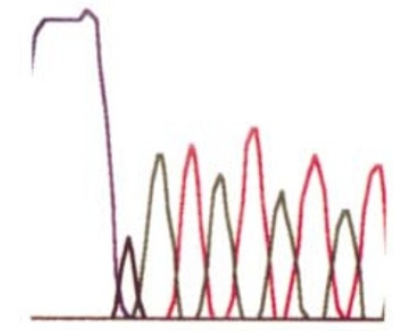

E70

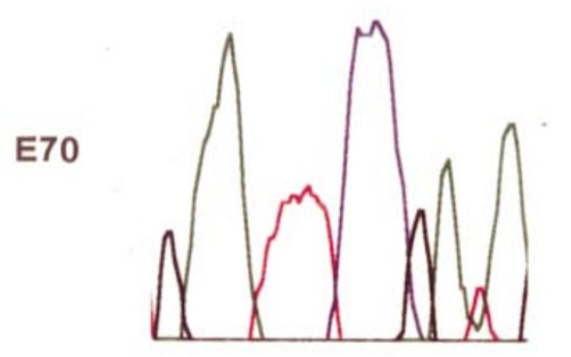

D286

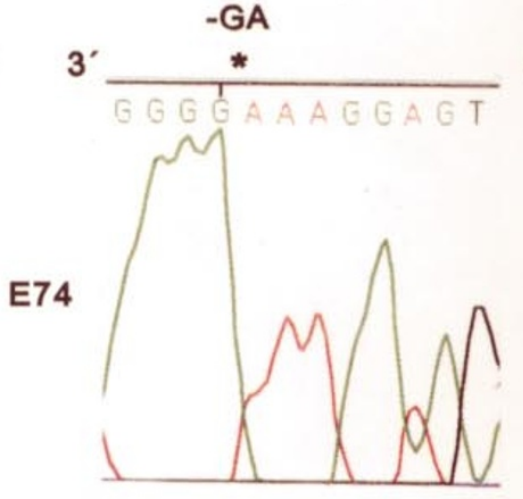

D320

Figure 1 A) SSCA of exon 66 (silver staining) and exons 62, 70, 74 (autoradiography) of the dystrophin gene in probands D 363, D 165, D 171, D 074 (and his mother), D 286 and D 320 in comparison with normal controls. The mobility shift of proband D 317 was found to be a polymorphism since it was also present in normal controls. B) Part of direct sequencing of exons 66, 62, 70, 74 (including intron boundaries) of patients demonstrating a band shift in SSCA. Sequencing revealed six pathogenic mutations: three microdeletions (D 165, D 171, and D 320), one donor splice site mutation (D 286), and two substitutions creating stop codons (D 074 and $\mathrm{D} 363)$. A sterisks demonstrate the site of nucleotide change. 
Table 1 Clinical data of patients with pathogenic minor changes

\begin{tabular}{lllllll}
\hline $\begin{array}{l}\text { Patient } \\
\text { N o }\end{array}$ & $\begin{array}{l}\text { A geat } \\
\text { diagnosis } \\
\text { (years) }\end{array}$ & $\begin{array}{l}\text { Famillial (F)/ } \\
\text { Sporadic (S) }\end{array}$ & D iagnosis & $\begin{array}{l}\text { CK level } \\
\text { (IU/L ) }\end{array}$ & $\begin{array}{l}\text { Muscle } \\
\text { biopsy }\end{array}$ & $\begin{array}{l}\text { M ental } \\
\text { retardation }\end{array}$ \\
\hline D 074 & 6 & S & D M D & 11000 & no & ++ \\
D 165 & 4 & F & D M D & 8000 & yes & +++ \\
D 171 & 5 & F & D M D & 11560 & no & +++ \\
D 286 & 8 & F & D M D & 7000 & no & +++ \\
D 320 & 13 & S & B M D & 7600 & no & - \\
D 363 & 5 & F & D M D & 10000 & yes & +++ \\
\hline
\end{tabular}

L evel of MR: +++ (severe), ++ (moderate), - (absence).

Table 2 M inor changes in the distal part of the dystrophin gene in G reek DMD/BM D patients

\begin{tabular}{|c|c|c|c|c|c|}
\hline Patient N 0 & $\mathrm{Exon}^{\mathrm{a}}$ & Nucleotide change $\mathrm{e}^{\mathrm{b}, \mathrm{c}}$ & $\mathrm{Name}^{\mathrm{c}}$ & M utation & Expected translational effect \\
\hline $\mathrm{D} 074$ & 62 & G 9391A & W 3061X & nonsense & truncation \\
\hline D 171 & 66 & $\begin{array}{l}\text { deletion of } \\
\text { TG TA A A G C between } \\
9827 \text { and } 9834\end{array}$ & 9827del8 & frameshift & $\begin{array}{l}\text { truncation } \\
\text { (stop codon } 21 \text { codons } \\
\text { downstream) }\end{array}$ \\
\hline D 363 & 66 & С9776Т & R 3190X & nonsense & truncation \\
\hline D 165 & 66 & $\begin{array}{l}\text { deletion of } A \text { A } \\
\text { between } 9806 \text { and } 9807\end{array}$ & 9806delA A & frameshift & $\begin{array}{l}\text { truncation } \\
\text { (stop codon } 8 \text { codons downstream) }\end{array}$ \\
\hline D 286 & 70 & G --->C at +1 intron 70 & $10431+1 G-->C$ & splice site & three truncated products ${ }^{d}$ \\
\hline D 320 & 74 & $\begin{array}{l}\text { deletion of G A } \\
\text { between } 10716 \text { and } 10717\end{array}$ & 10716delGA & frameshift & $\begin{array}{l}\text { altered size product }^{d} \\
\text { (deletion of } 110 \text { amino acids) }\end{array}$ \\
\hline
\end{tabular}

${ }^{a}$ A ccording to R oberts et $\mathrm{al}^{2}{ }^{\mathrm{b}}{ }^{\mathrm{b}} \mathrm{N}$ ucleotide and amino acid numbering according to Koenig et $\mathrm{al}^{3}{ }^{\mathrm{c}}{ }^{\mathrm{c}} \mathrm{N}$ omenclature according to $\mathrm{B}$ eaudet and T sui ${ }^{22} ;{ }^{d}$ R esults from RT-PCR study of PBL transcripts.

of the 250-bp band revealed complete loss of exon 68 and a 101-bp deletion in exon 70 (nucleotides 10330-10401), as a cryptic splice site was used (dinucleotide GT at 10331-2 of exon 70). The 370-bp fragment of the patient revealed a product with total loss of exon 70 . The product of $410 \mathrm{bp}$ demonstrated 101 bp deletion in exon 70, the same as was previously described for the 250-bp band. A II fragments had lost the altered donor splice site of intron 70 , and frameshifts are expected in the translational reading frame.

\section{A Microdeletion in Exon 74}

In exon 74, SSCA demonstrated a mobility shift in patient D 320 (Figure 1A ). D irect sequencing showed a GA microdeletion in the coding area (Figure 1B). RT-PCR analysis was performed for the region between nucleotides 9974 and 11297 (exons 67-77) and showed only one shorter product (about $1000 \mathrm{bp}$ ) instead of the expected normal $1325 \mathrm{bp}$ (Figure 2B). $D$ irect sequencing of the product revealed the complete loss of exons 71-74 (Figure 2B). A Ithough mutation at genomic DNA level creates a frameshift in the reading frame, at CDNA level the reading frame is restored, lacking only the coding sequences of skipping exons (110 aminoacids).

\section{Distribution of Mutations}

Figure 3 presents the minor mutations identified in this study compared with those obtained from two databases for the corresponding region (January 1998). The sites of the two databases are http://www.dmd. $\mathrm{nl}^{23}$ and http://www.uwcm.ac.uk/uwcm/mg/hgmd0.html. ${ }^{24}$

\section{Discussion}

We used PCR-SSCA of exons 60-79 of the dystrophin $C$-terminal domain to screen for minor changes in $35 \mathrm{Greek}$ DMD/BMD patients. Four out of seven patients with severe MR had minor changes at the $3^{\prime}$ end of the dystrophin gene. It is interesting that although this gene region represents only $25 \%$ of the entire coding region of the gene in our study there is a cluster of minor changes in patients with $M R$. These findings support previous screening data ${ }^{15}$ as well as reports of isolated cases ${ }^{11,25,26}$ that implicate mutations in the distal part of the human dystrophin gene of some 
A

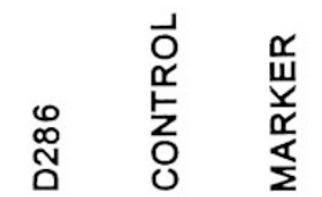

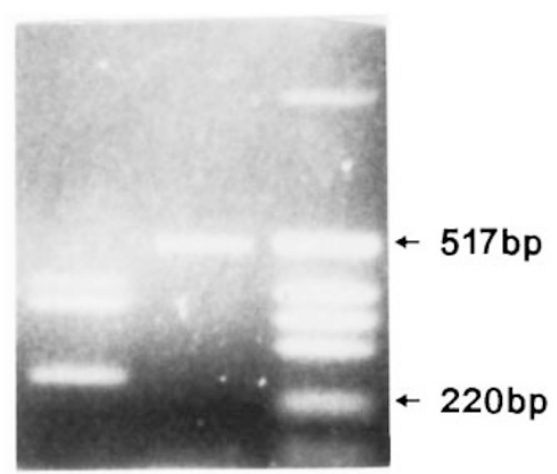

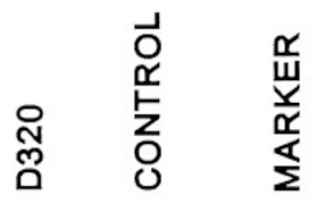

$\leftarrow 1600 \mathrm{bp}$

$\leftarrow 1000 \mathrm{bp}$

B

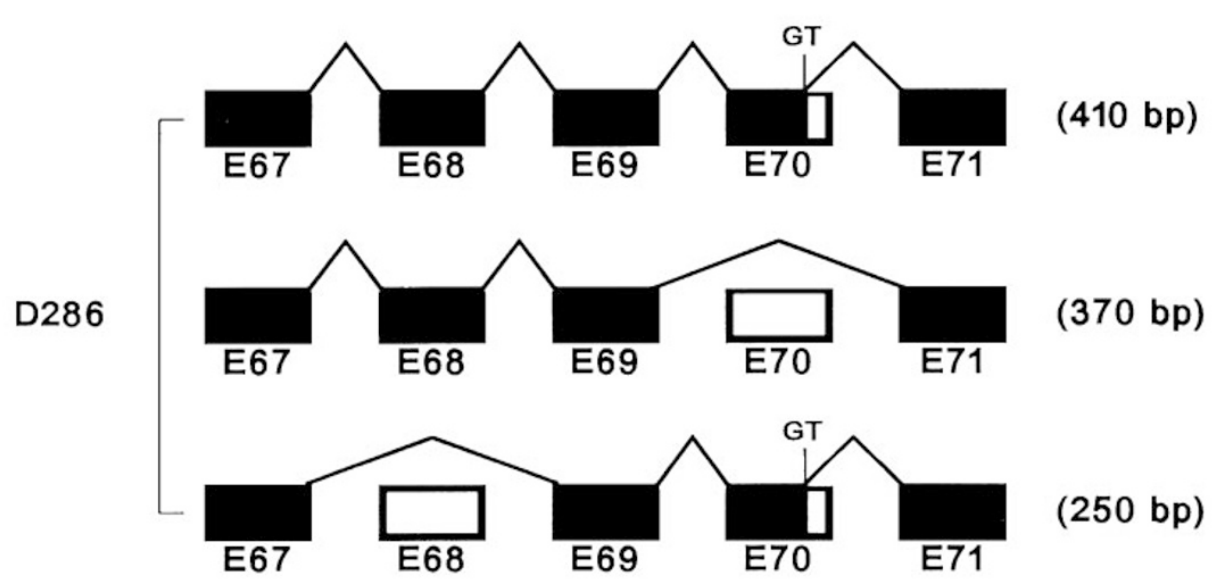

D320

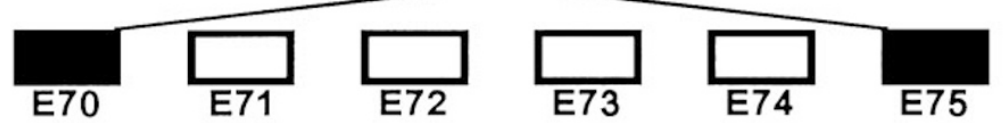

(1000 bp)

Figure 2 A) $2 \%$ agarose gel electrophoresis of products of nested RT-PCR from patient D286 (left), spanning nucleotides 9973-10480 and from patient D 320 (right) spanning nucleotides 10213-10891. The probands' products displayed shorter bands than the normal controls indicating exon(s) loss. Marker $1 \mathrm{~kb}$ molecular weight marker (BRL, USA), bp: base pairs. B) Schematic presentation of the splicing effect on $\mathrm{mRNA}$ transcripts from the donor splice site mutation of patient $\mathrm{D} 286$ and from the microdeletion of patient D 320. Solid boxes: regions that are retained in CDNA; blank boxes: regions that are missing from mR NA transcript; G T cryptic splice site 


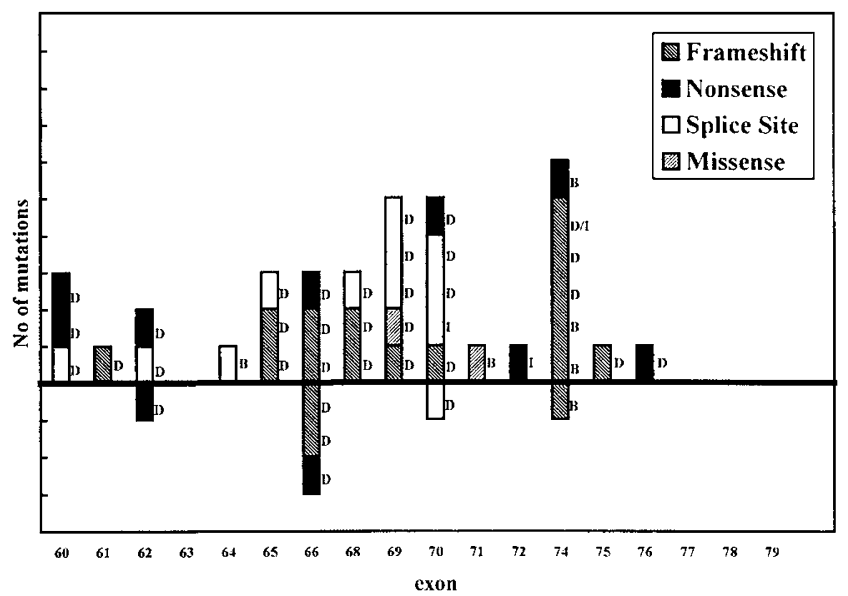

Figure 3 D istribution of minor changes detected in this study at the distal part of the dystrophin gene (beneath the horizontal line) compared with the small lesions of the corresponding area obtained from two databases (above the horizontal line). D: Duchenne muscular dystrophy; I: Intermediate muscular dystrophy; B : Becker muscular dystrophy.

$D M D$ patients with MR. This could be the result of disruption of the C-terminal isoforms (D p140, D p116 and D p71) which are mainly expressed in the nervous system and also interact with sarcolemmal proteins. ${ }^{27}$ However, further data will be necessary in order to establish correlation of mutations located in the $3^{\prime}$ end of the dystrophin gene with M R. In recent years several studies, most of them in vitro assays, have investigated and revealed critical domains in the interaction of dystrophin with other proteins. ${ }^{28} \mathrm{~A}$ nother approach to clarifying the role of distinct dystrophin domains is to study the effect of specific mutations of the dystrophin gene in relation to the clinical phenotype. ${ }^{25}$

The three different minor alterations that were found in exon 66 in three unrelated DMD patients are predicted to lead to premature termination of the protein. Furthermore, the pathogenic role of the detected mutations was supported by haplotype analysis available for two families (probands D165 and D 171).

The incidence of three different minor changes in the same exon led us to search GenBank/E MBL/DDBJ/ PD B databases using BLA ST ${ }^{29}$ for any similarity. The search showed that 36 bases of exon 66 ( $85 \mathrm{bp}$ in length) present $80 \%$ similarity with the 265 genomic $M R N A$ of eastern equine encephalomyelitis virus (EEEV). Two of the three mutations that were found in exon 66 , both microdeletions, were detected in this part of the dystrophin sequence. It is interesting that the frameshift mutation of patient D 165 generates a stop codon eight codons downstream and shows short motif matches of four aminoacids with the viral protein. The 26S virus mRNA codes the nonstructural protein for its capsid, using a different reading frame from dystrophin. ${ }^{30}$ The virus is an RNA (plus-strand) which infects many organisms, including human, causing neuroradiographic abnormalities best visualised by magnetic resonance imaging $(\mathrm{MRI}) .^{31}$

The small cluster of three alterations at exon 66 in our patients (Figure 3 ) may be due to the conditions of our technique or to the fact that this analysis was performed on $\mathrm{G}$ reek patients only. Previous studies in the $G$ reek population have also described differences in deletion breakpoints and in recombination events in the STR 44-50 region of the dystrophin gene. ${ }^{32,33}$ $M$ oreover, the incidence of the polymorphism $C$ to $T$ at position +15 of intron 66, in Greek population, is found with a frequency of $15 \%$ which is greater than the $5 \%$ frequency reported by Lenk et al. ${ }^{15}$

The three frameshift products that were revealed by CD NA analysis in patient D 286 demonstrate the usage of the alternative splicing mechanism. This property of the carboxy terminus of the gene is also evident in the case of B M D patient D 320 in whom the D NA defect on exon 74 activates exon skipping and finally restores the frameshift mutation. It must be pointed out that even though our results are obtained from ectopic transcripts and not from muscle mRNA they are consistent with the phenotypic expression. D espite the speculation that the integrity of the C-terminal domain is critical for protein function ${ }^{7}$ the BM D phenotype of patient $D 286$ indicates that absence of exons 71-74 is not critical enough to cause severe phenotype. Our findings are compatible with the finding of several normal features in the muscle of an mdx mouse that bears a deletion of exons $71-74 .{ }^{34}$ A s Figure 3 shows, mutations at exon 74 are reported in cases with different phenotypes and some of them (BMD and IMD) were inconsistent with the nature of mutation. In one of these cases RNA study was available but failed to explain the mild phenotype. ${ }^{35}$ Phenotypic variation was also observed in deletions of certain exons and according to Sheratt et al this may be due to both the different efficiency of alternative splicing and to the abundance of dystrophin positive fibres. ${ }^{36}$

The mutation in exon 62 of proband D 074 is predicted to result in lack of the entire cysteine-rich region and carboxy terminus domain which is compatible with the DMD phenotype. ${ }^{37}$ The absence of point mutation in the grandfather provides strong evidence that the mutation is responsible for the DMD phenotype. It is 
remarkable that two other mutations that have been described in exon 62 are observed in DMD patients with M R or speech delay and accord with the moderate mental deficiency of our patient. ${ }^{35}$

To our knowledge, with the exception of the splice site mutation, the remaining five minor alterations that are reported here have not been described so far in the literature. Characterisation of these mutations provides more information about the role of distinct exons in the distal part of the dystrophin gene in relation to the phenotypic expression.

\section{Acknowledgements}

The authors are indebted to D r J Traeger-Synodinos for her scientific advice and A Botsonis for his help on database searching. $K K$ is the recipient of a grant from the $A$ thens U niversity R esearch Institute for the Prevention and Treatment of $G$ enetic and $M$ alignant $D$ iseases of $C$ hildhood and of a fellowship from the A cademy of $A$ thens.

\section{References}

1 Koenig M, H offman E P, B ertel son CI, M onaco A P, Feener $C$, Kunkel LM: Complete cloning of the Duchenne muscular dystrophy (DMD) CD NA and preliminary genomic organisation of the DM D gene in normal and affected individuals. Cell 1987; 50: 509-517.

2 Roberts R G, Coffey A J, Bobrow M, B entley DR : D etermination of the exon structure of the distal portion of the dystrophin gene by vectorette PCR. G enomics 1992; 13: 942-950.

3 Koenig $M$, Monaco AP, Kunkel LM: The complete sequence of dystrophin predicts a rod-shaped cytoskeletal protein. Cell 1988; 53: 219-228.

4 A rahata $\mathrm{K}$, I shiura S, Tsukahara $\mathrm{T}$ et al: I mmunostaining of skeletal and cardiac muscle surface membrane with antibody against Duchenne muscular dystrophy peptide. Nature 1988; 333: 861-863.

5 Den Dunnen JT, Grootscholten PM, Bakker E et al: Topography of the D uchenne muscular dystrophy (DMD) gene: FIGE and CDNA analysis of 194 cases reveals 115 deletions and 13 duplications. A m J H um G enet 1989; 45: 835-847.

6 A bbs S, Yau SC, Clark S, M athew CG, Bobrow M: A convenient multiplex PCR system for the detection of dystrophin gene deletions: a comparative analysis with CD NA hybridisation reveals mistypings by both methods. J Med G enet 1991; 28: 304-311.

7 R oberts R G, Gardner R, B obrow M: Searching for 1 in 2400000: A review of dystrophin gene point mutations. H um M ut 1994; 4: 1-11.

$8 \mathrm{~A} h \mathrm{~h}$ A, Kunkel L: The structural and functional diversity of dystrophin. Nat G enet 1993; 3: 283-291.

9 Tinsley J M, Blake D J, R oche A et al: Primary structure of dystrophin-related protein. Nature 1992; 360: 591-593.
10 Feener CA , K oenig M , Kunkel L M : A Iternative splicing of human dystrophin mRNA generates isoforms at the carboxy terminus. N ature 1989; 338: 509-511.

11 Tuffery S, Lenk U, Roberts R, Coubes C, Demaille J, Claustres $M$ : Protein truncation test: analysis of two novel point mutations at the carboxy-terminus of the human dystrophin gene associated with mental retardation. $\mathrm{H}$ um M ut 1995; 6: 126-135.

12 R apaport D, Lederfein D, D en D unnen JT et al: Characterisation and cell type distribution of a novel, major transcript of the Duchenne muscular dystrophy gene. Different 1992; 49: 187-193.

13 Byers TJ, Lidov HG, Kunkel L M : A $n$ alternative dystrophin transcript specific to peripheral nerve. $\mathrm{N}$ at $\mathrm{G}$ enet 1993; 4: 77-81.

14 Lidov H, Selig S, Kunkel L: D p140: A novel 140 kD a CN S transcript from the dystrophin locus. Hum Mol Genet 1995; 4: 329-335.

15 Lenk $U, H$ anke $R$, Thiele $H$, Speer A : Point mutations at the carboxy terminus of the human dystrophin gene: implications for an association with mental retardation in DMD patients. H um Mol G enet 1993; 2: 1877-1881.

$16 \mathrm{M}$ atsumura $\mathrm{K}$, Tome $\mathrm{FM}$, I onasescu $\mathrm{V}$ et al: D eficiency of dystrophin-associated proteins in Duchenne muscular dystrophy patients lacking $\mathrm{COOH}$-terminal domains of dystrophin. J Clin I nvest 1993; 92: 866-871.

17 I braghimov-B eskrovnaya O, Ervasti J M, Leveille CJ, Slaughter CA, Sernett SW, Campbell K P: Primary struCture of dystrophin associated glycoproteins linking dystrophin to the extracellular matrix. Nature 1992; 355: 696-702.

18 M ountford R: PCR Techniques for D eletion, $L$ inkage, and mutation A nalysis in Duchenne/Becker muscular dystrophy. From: M ethods in M olecular medicine: molecular diagnosis of genetic diseases. E dited by: R. E lles H umana Press Inc., Totowa, NJ 1996.

19 Chellly J, Kaplan J C, Maire P, Gautron S, Kahn A: Transcription of the dystrophin gene in human muscle and non-muscle tissues. Nature 1988; 33: 858-860.

20 Roberts R G, B arby TF, M unners E, Bobrow M, Bentley $D R$ : D irect detection of dystrophin gene rearrangements by analysis of dystrophin mRNA in peripheral blood lymphocytes. A m J H um G enet 1991; 49: 298-310.

21 Lasa A, G allano P, Balget M : Three novel point mutations in the dystrophin gene in DM D patients. H um M ut 1997; 9: 473-474.

22 Beaudet $A L$, Tsui $L C$ : A suggested nomenclature for designating mutations. $\mathrm{H}$ um $\mathrm{M}$ ut 1993; 2: 245-248.

23 den Dunnen JT, Bakker E: D uchenne/B ecker muscular dystrophy data pages 1996; www address: http/ /www.dmd.nl

24 Krawczak $M$, Cooper DN: Human gene mutation data base. Trends $\mathrm{G}$ enet 1997; 13: 121-122.

25 Lenk $U, 0$ exle $K, V$ oit T et al: A cysteine 3340 substitution in the dystroglycan-binding domain of dystrophin associated with Duchenne muscular dystrophy, mental retardation and absence of the ER G b-wave. Hum M ol Genet 1996; 5(7): 973-975.

26 Comi GP, Ciafaloni $E$, de Silva HAR et al: A GA ${ }^{+1}$ transversion at the $5^{\prime}$ splice site of intron 69 of the dystrophin gene causing the absence of peripheral nerve D p116 and severe clinical involvement in a D M D patient. H um Mol G enet 1995; 4(11): 2171-2174. 
27 G reenberg D, Schatz Y, L evy Z, Pizzo P, Y affe D, Nydel U : Reduced levels of dystrophin associated proteins in the brains of mice deficient for D p71. H um M ol G enet 1996; 5: 1299-1303.

28 Winder S: The membrane-cytoskeleton interface: the role of dystrophin and utrophin. J M us Res Cell Motil 1997; 18: 617-629.

29 A Itschul SF, Gish W, Miller W, Myers EW, Lipman DJ: Basic local alignment search tool. J M ol Biol 1990; 215: 403-410.

30 Chang G-J, Trent DW: N ucleotide sequence of the genome region encoding the $26 \mathrm{~S} \mathrm{mRNA}$ of eastern equine encephalomyelitis virus and the deduced amino acid sequence of the viral structural proteins. J G en Virol 1987; 68: $2129-2142$.

31 D eresiewicz R L, Thaler SJ, H su L, Z amani A : Clinical and neuroradiographic manifestations of eastern equine encephalitis. N Engl J Med 1997; 336: 1867-1874.

32 Florentin L, Bili C, Kekou K, Tripodis N, Mavrou A, $M$ etaxotou $C$ : $M$ apping dystrophin gene recombinants in G reek DMD/BMD families: low recombination frequencies in the STR region. H um G enet 1995; 96: 423-426.
33 Florentin L, M avrou A, K ekou K, M etaxotou C: Deletion patterns of $D$ uchenne and B ecker muscular dystrophies in G reece. J $M$ ed G enet 1995; 32: 48-51.

34 R afael JA, Sunada Y, Cole NM, Campbell KP, Faulkner JA, Chamberlain JS: Prevention of dystrophic pathology in mdx mice by a truncated dystrophin isoform. $\mathrm{H}$ um M ol Genet 1994; 3: 1725-1733.

$35 \mathrm{G}$ ardner RJ, B obrow M, R oberts R: The identification of point mutations in $\mathrm{D}$ uchenne muscular dystrophy patients by using reverse-transcription PCR and the protein truncation test. A m J H um G enet 1995; 57: 311-320.

36 Sherratt T, Vulliamy T, D ubowitz V, Sewry C, Strong P: Exon skipping and translation in patients with frameshift deletions in the dystrophin gene. A m J H um G enet 1993; 53: 1007-1015.

37 Bies R, Caskey T, Fenwick R: A n intact cysteine-rich domain is required for dystrophin function. J Clin Invest 1992; 90: 666-672. 